\title{
Scholars and Literati in European Academia before 1800
}

\author{
David de la Croix \\ IRES/LIDAM, UCLouvain
}

\section{INTRODUCTION}

This note is a progress report on the establishment of a relational database of scholars and literati active in European Academia from the inception of the first universities to the dawn of the Industrial Revolution. This database is a necessary tool to quantify the role of academia in the "Rise of the West”, using the methods of economics and statistics.

The compilation of the database started in 2017 and now (in October 2021) contains data on more than 50,000 persons active in 400 universities and academies. The project was first funded by 'Special Research Funds' from UCLouvain, then by the European Research Council (ERC). The ERC grant falls under the European Union's Horizon 2020 research and innovation programme, grant agreement No. 883033 "Did elite human capital trigger the rise of the West? Insights from a new database of European scholars."

We harvest data manually from secondary sources on the history of universities and academies. We took the list of universities from Frijhoff (1996) and the list of academies from McClellan (1985), and added to this the language academies, the most important Italian Renaissance academies from The British Library (2021), and several other higher education institutions which conferred academic degrees.

Starting in 2021,once data collection for a given institution is complete, we produce an issue of the Repertorium Eruditorum totius Europae (RETE), providing a short description of the institution and the source used, together with some descriptive statistics.

In this issue of RETE, I provide an overview of the whole work as it stands now.

\section{SOME STATISTICS}

Table 1 shows some descriptive statistics, which can easily be compared with statistics on individual institutions provided in the other issues of RETE. The whole period is divided into eight sub-periods, corresponding to major historical events: from the urban revolution to the first universities (10001199); from the official foundation of Paris and Oxford in 1200 to the Black Death (1200-1347); from the Black Death to the invention of the movable-type printing press (1348-1449); from the printing press to the rise of Protestantism and the foundation of the first Protestant university in Marburg (1450-1526); from Protestantism to the beginning of the Thirty Years' War (1527-1617); from the Thirty Years' War to the revocation of the Edict of Nantes (1618-1684); from this revocation to the rise of Enlightened universities and the foundation of the University of Göttingen (1685-1733); and from Enlightened universities to 1800 (1734-1800).

The percentage of persons for whom the birth year is known, even approximately, is particularly high during the first period, because of a selection effect: the people we know about from that period are relatively famous, and better documented. A more "normal" percentage is around 12-18\% during the Middle-Ages. In the Early Modern Period, it increases steadily.

With regard to longevity, we observe the same selection effect for the first period. Our two measures (mean age at death, and expected age at death when 30) drop after 1450, which is hard to 
interpret. Finally, in accordance with the literature on the historical life expectancy of elites (Stelter, De la Croix, and Myrskylä 2021), longevity improves in the last two periods.

We know the birthplace of $70 \%$ of the scholars, and this percentage is more or less constant through time.

Finally, $26.2 \%$ of the scholars have a Wikipedia page (in some language), and $40.2 \%$ of them have left a footprint in the catalogues of the libraries of the world, Worldcat, either by having published some work, or by having been the subject of published books and articles. For scholars active before the invention of the printing press, more have a Wikipedia page than a Worldcat reference, as several publications of that time did not survive or are not available in the libraries today. Conversely, following the invention of the printing press we see more scholars with publications than with a Wikipedia page.

\begin{tabular}{|c|c|c|c|c|c|c|}
\hline \multicolumn{2}{|c|}{ Period } & \multirow{2}{*}{$\begin{array}{l}\text { nb. } \\
\text { obs }\end{array}$} & \multirow{2}{*}{$\begin{array}{c}\% \text { birth year } \\
\text { known }\end{array}$} & \multirow{2}{*}{$\begin{array}{l}\text { mean age } \\
\text { at appoint. }\end{array}$} & \multirow{2}{*}{$\begin{array}{c}\text { mean age } \\
\text { at death }\end{array}$} & \multirow{2}{*}{$\begin{array}{l}\text { exp. age } \\
\text { at death }\end{array}$} \\
\hline Start & End & & & & & \\
\hline 1000 & 1199 & 291 & 37.1 & 35.1 & 67.2 & 68.2 \\
\hline 1200 & 1347 & 1895 & 15.9 & 35 & 65.4 & 65.5 \\
\hline 1348 & 1449 & 4481 & 12.4 & 32.3 & 65.7 & 66.4 \\
\hline 1450 & 1526 & 6540 & 17.6 & 31.9 & 62.3 & 62.6 \\
\hline 1527 & 1617 & 9200 & 39.7 & 32.8 & 62.1 & 62 \\
\hline 1618 & 1685 & 8941 & 51 & 35.2 & 62.8 & 61.7 \\
\hline 1686 & 1733 & 7237 & 60.4 & 35.8 & 64.1 & 63.2 \\
\hline 1734 & 1800 & 13962 & 73.2 & 35.9 & 65.7 & 64.9 \\
\hline \multirow[t]{3}{*}{1000} & 1800 & 52547 & 47.4 & 35 & $6 \overline{4} . \overline{2}$ & 63.6 \\
\hline & & & $\%$ birth place & & $\%$ with & $\%$ with \\
\hline & & & known & & Wikipedia & Worldcat \\
\hline 1000 & 1199 & & 72.9 & & 49.5 & 49.1 \\
\hline 1200 & 1347 & & 63.4 & & 20.4 & 19.8 \\
\hline 1348 & 1449 & & 70.5 & & 9.7 & 9.1 \\
\hline 1450 & 1526 & & 66.4 & & 11.5 & 16 \\
\hline 1527 & 1617 & & 72.4 & & 23.2 & 38.3 \\
\hline 1618 & 1685 & & 69.8 & & 25.7 & 42.9 \\
\hline 1686 & 1733 & & 67.6 & & 28.2 & 47.9 \\
\hline 1734 & 1800 & & 73.2 & & 40.1 & 59.7 \\
\hline 1000 & 1800 & & 70.3 & & $2 \overline{6} . \overline{2}$ & 40.2 \\
\hline
\end{tabular}

Table 1: Summary statistics by period

\section{FIELDS}

Figure 1 shows the relative importance of academic fields, broadly defined. Law increased in importance from the first to the second period with the rediscovery of Roman law, and then suffered a relative decline over time. Theology starts with a big share, then declines in periods 3 and 4, before regaining importance with the Protestant reformation. Humanities became dominant with the humanistic revolution in period 4. Medicine has always had a presence, while Sciences gain in importance in the last two periods. Applied sciences emerged during the last period. 
Composition by field, period $1000-1199$

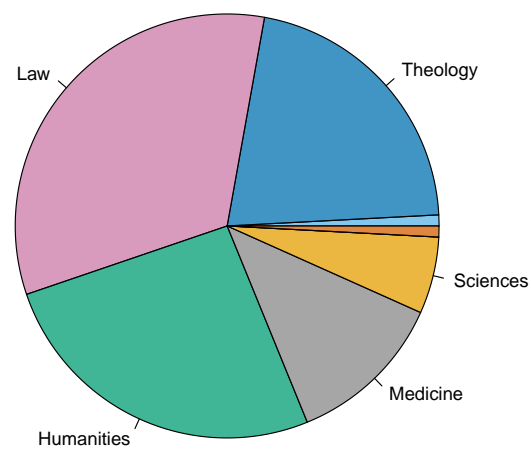

Composition by field, period 1348-1449

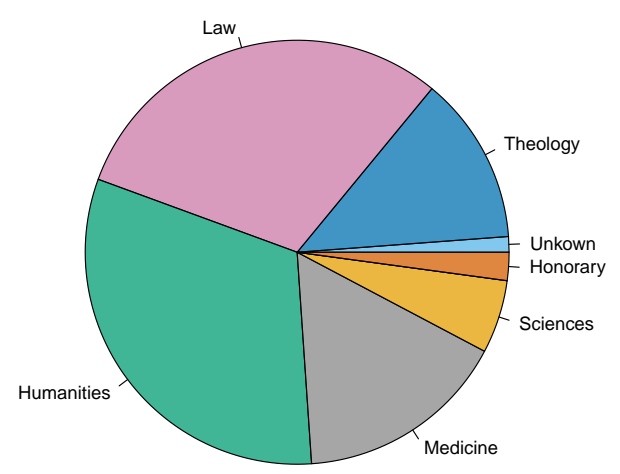

Composition by field, period 1527-1617

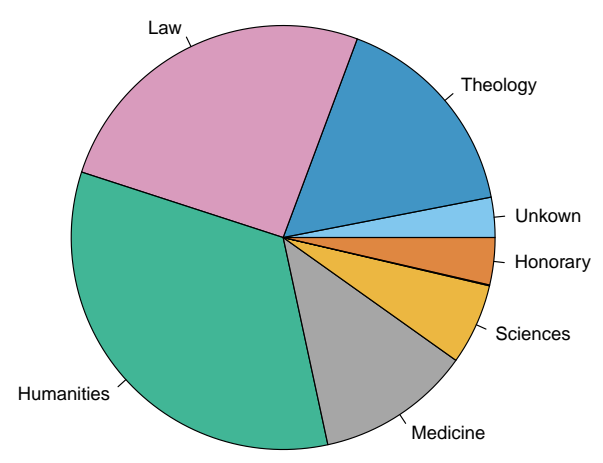

Composition by field, period $1686-1733$

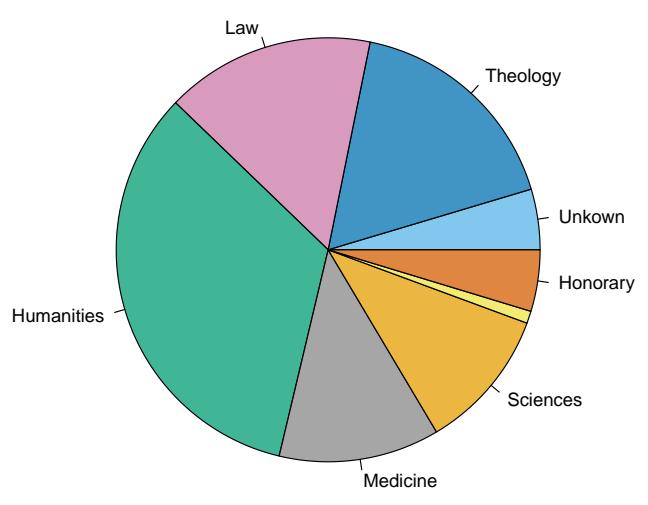

Composition by field, period 1200-1347

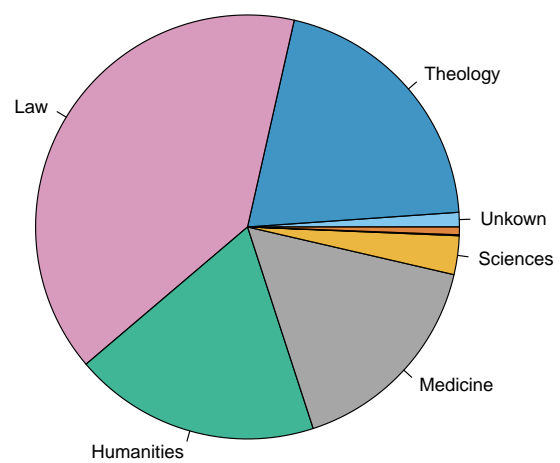

Composition by field, period 1450-1526

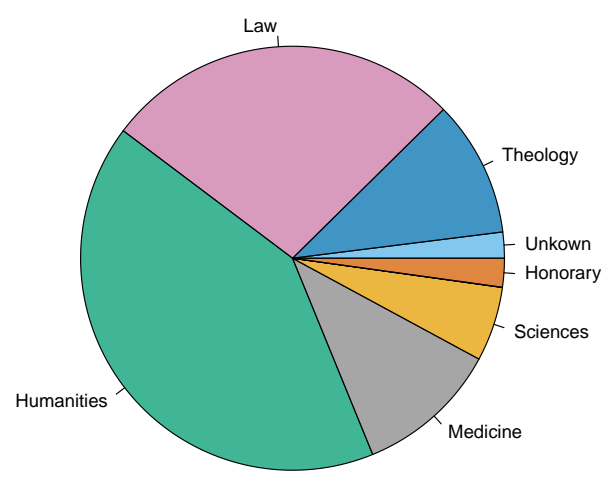

Composition by field, period 1618-1685

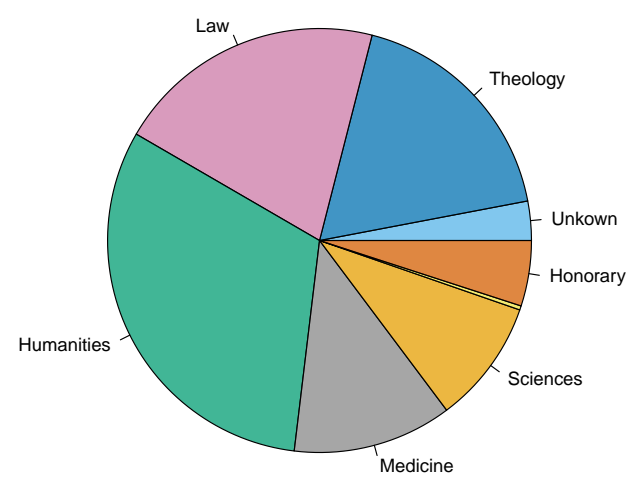

Composition by field, period 1734-1800

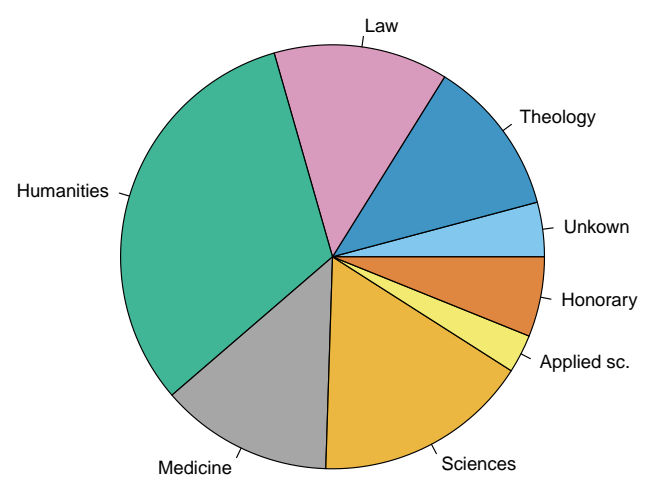

Figure 1: Broad academic fields 

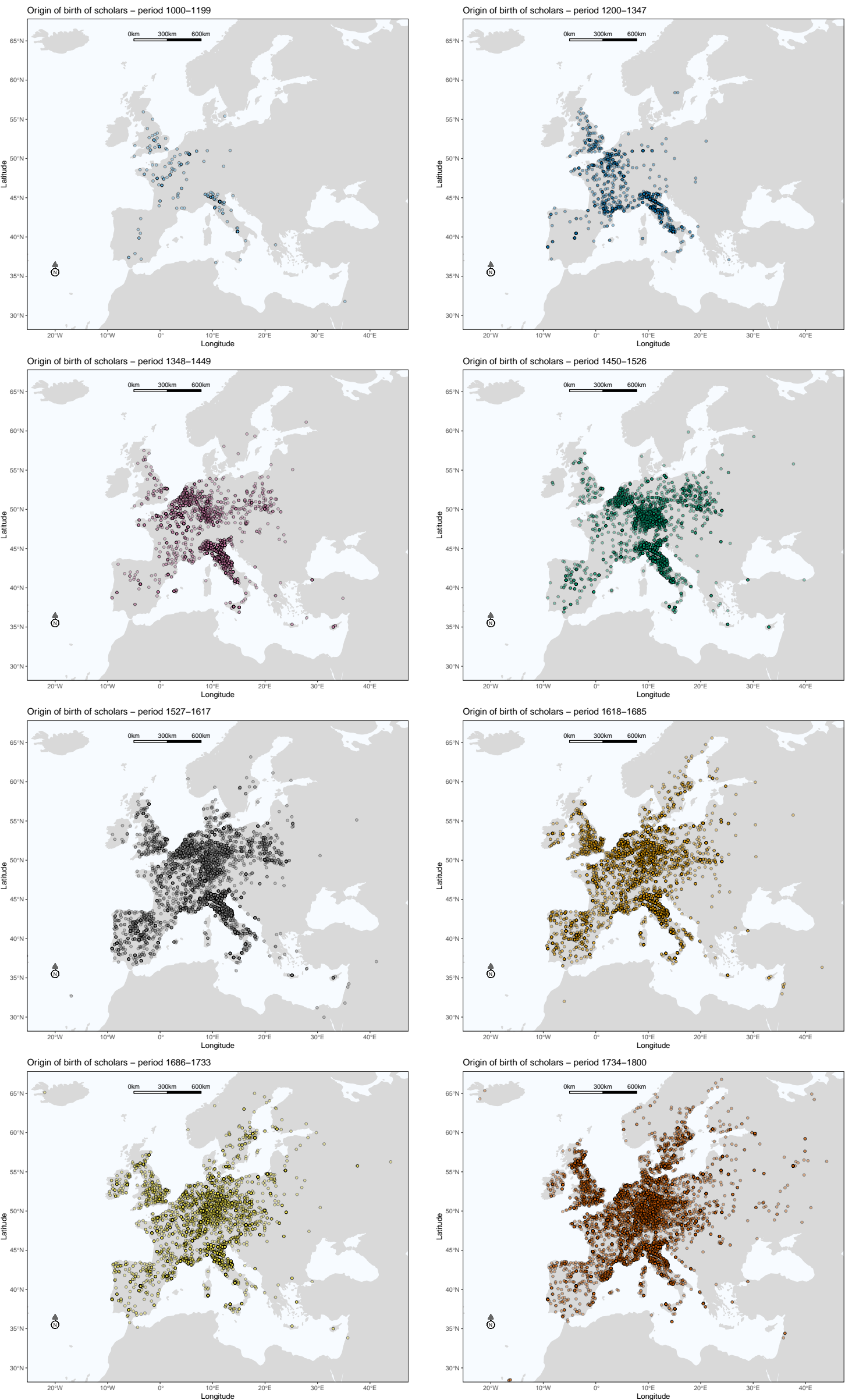

Figure 2: Place of birth of the scholars and literati 


\section{Place OF BIRTH}

Figure 2 is a plot of the places of birth of all the scholars, and shows the geographical coverage of our database, by period. As the data collection is not complete, it may reflects gaps in the coverage, but the general trend of the expansion to the East is probably already correct. On the whole, we cover "Christian Europe" from Sevilla to Saint Petersburg.

\section{BARYCENTER}

Figure 3 shows the barycenter, with coordinates $R$. If each scholar $i$ is born in space with coordinates $r_{i}$, the barycenter is such that:

$$
\sum_{i}\left(r_{i}-R\right)=0
$$

It gives equal mass to each scholar. It is the center of mass of a distribution of birthplace in space, sometimes referred to as the balance point. The figure shows that the barycenter moves East then North as time passes.

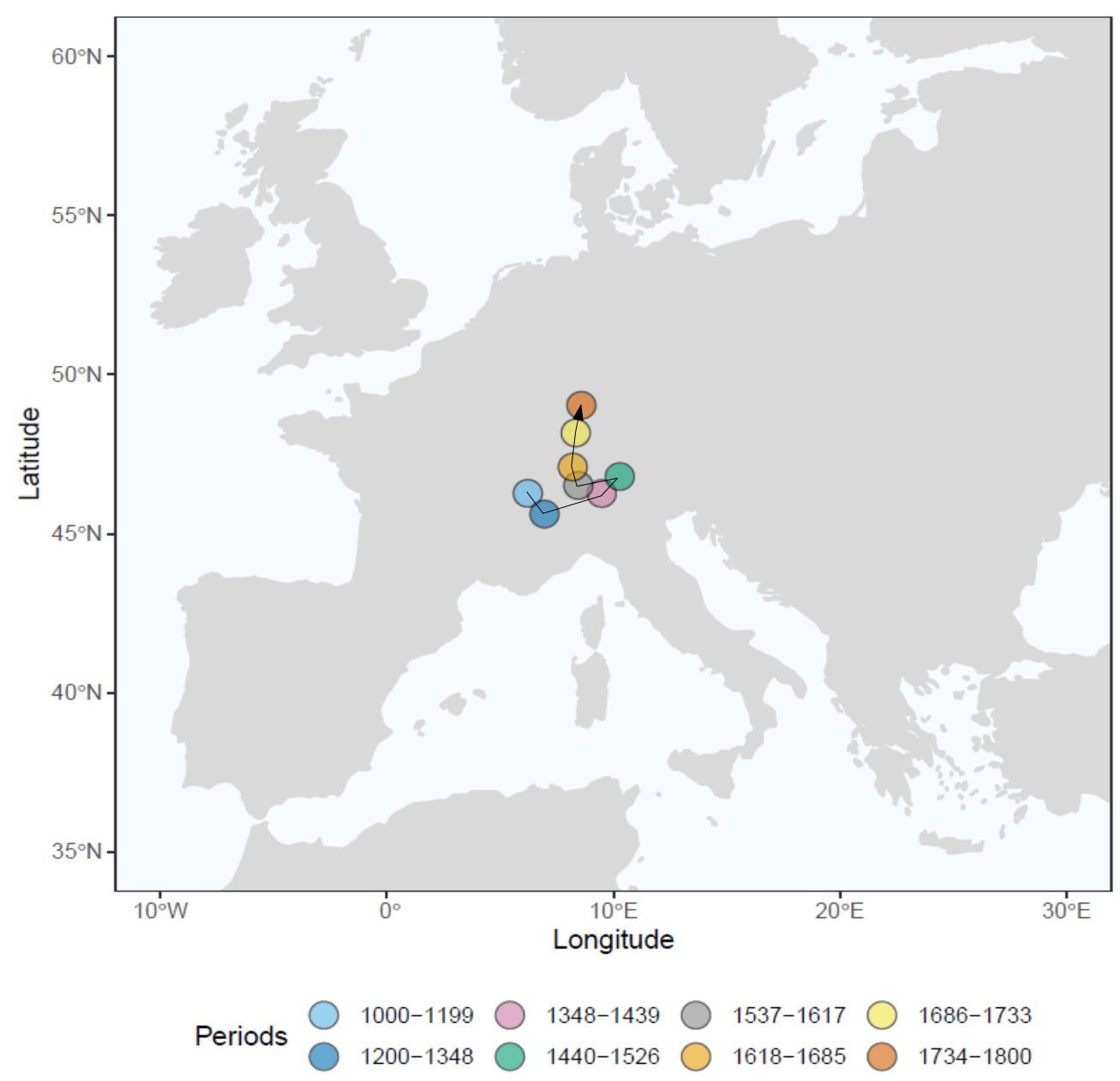

Figure 3: Barycenter of places of birth, by period

\section{HUMAN CAPITAL OF SCHOLARS AND LITERATI}

For each person in the database we compute a heuristic human capital index, identified by combining information from Worldcat and Wikipedia using a principal component analysis. More precisely, the 
individual human capital index $q_{i}$ of an individual $i$ is given by:

$$
\begin{aligned}
q_{i}= & -1.76+0.43 \ln (\mathrm{nb} . \text { characters of the longest Wikipedia page }) \\
& +0.40 \ln (\mathrm{nb} . \text { Wikipedia pages in different languages })+0.47 \ln (\mathrm{nb} \text {. works in Worldcat }) \\
& +0.46 \ln (\mathrm{nb} \text {. publication languages in Worldcat })+0.47 \ln (\mathrm{nb} \text {. library holdings in Worldcat })
\end{aligned}
$$

We assume that having no Wikipedia page is similar to having one page with a length of 60 characters and that having no Worldcat page is similar to having a page with one work in one language held by one library. The constant -1.76 normalizes $q_{i}$ at 0 when there is neither a Wikipedia page, nor a Worldcat page. The weights $(0.43,0.40$, etc) are obtained from the first principal component of the five indicators (De la Croix et al. 2020).

Our top 20 persons are listed in Table 2 together with their affiliation, and the issue of RETE in which they are mentioned. In this list, we did not include the scholars who only appear as corresponding members of some academies (such as Diderot, Lessing or Franklin), or who only have a weak link with a university (such as Spinoza).

\begin{tabular}{lcll}
\hline Name & Index & Affiliation & RETE \\
\hline Martin Luther & 12.72 & U. Wittemberg & \\
François-Marie Arouet de Voltaire & 12.27 & multiple academies & $3: 1-9,4: 9-17$ \\
JC Friedrich von Schiller & 12.17 & U. Jena & $1: 25-32$ \\
Immanuel Kant & 12.09 & U. Königsberg, mult. academies & $3: 1-9$ \\
Niccolo Machiavelli & 11.75 & Studium Florence & \\
René Descartes & 11.61 & Mersenne Academy & $2: 7-12$ \\
Giovanni Boccaccio & 11.53 & Studium Florence & \\
Isaac Newton & 11.46 & U. Cambridge, Royal Soc. & \\
Thomas Aquinas & 11.4 & U. Paris & $3: 1-9$ \\
Gottfried Wilhelm von Leibniz & 11.4 & Prussian Academy, Royal soc. \\
Desiderius Erasmus & 11.4 & U. Freiburg, Louvain, Cambridge & $4: 53-66$ \\
Galileo Galilei & 11.26 & U. Pisa, Padova, mult. academies & $3: 33-42$ \\
John Locke & 11.24 & Royal Society & \\
Jonathan Swift & 11.17 & Acad. Dublin & \\
Jean Racine & 11.15 & Acad. Française & $1: 41-47$ \\
Johannes Calvin & 11.1 & U. Geneva & \\
David Hume & 11.03 & U. Edinburgh & $2: 7-12$ \\
Blaise Pascal & 11.03 & Mersenne Academy & \\
Francis Bacon & 11.02 & U. Cambridge & $2: 7-12$ \\
Thomas Hobbes & 10.93 & Mersenne Academy & \\
\hline
\end{tabular}

Table 2: Top 20 scholars, based on human capital index

\section{Universities vs. AcAdemies}

Figure 4 shows the sets of scholars at Universities after 1500, and at Academies. The intersection contains those present in the two types of institutions. It is far from empty, so there were overlaps between the two sorts of institutions.

\section{ACKNOWLEDGMENTS}

This project has received funding from the European Research Council (ERC) under the European Union's Horizon 2020 research and innovation programme under grant agreement No 883033 "Did elite human capital trigger the rise of the West? Insights from a new database of European scholars."

First version October 20, 2021. 


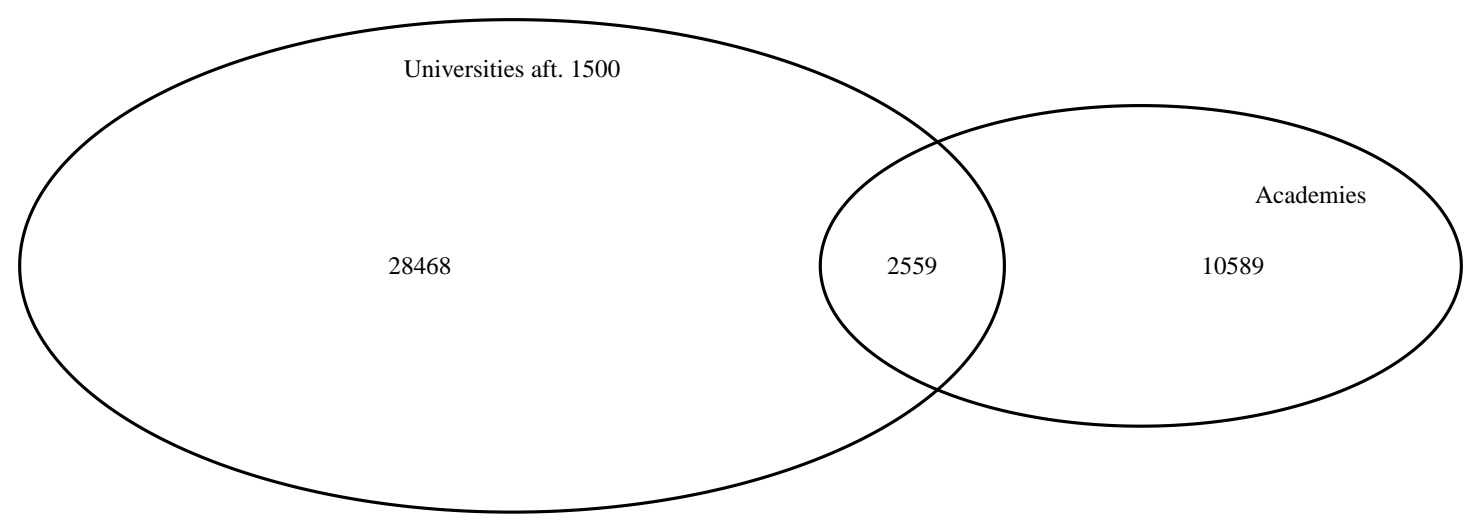

Figure 4: Intersections of the lists of scholars between Universities and Academies

\section{REFERENCES}

De la Croix, David, Frédéric Docquier, Alice Fabre, and Robert Stelter. 2020. "The Academic Market and the Rise of Universities in Medieval and Early Modern Europe (1000-1800).” CEPR Discussion Paper 14509.

Frijhoff, Willem. 1996. "Patterns." Chapter 2 of A History of the University in Europe. Vol. II: Universities in Early Modern Europe (1500-1800), edited by Hilde de Ridder-Symoens. Cambridge University Press.

McClellan, James E. 1985. Science reorganized: Scientific societies in the eighteenth century. Columbia University Press.

Stelter, Robert, David De la Croix, and Mikko Myrskylä. 2021. "Leaders and Laggards in Life Expectancy among European Scholars from the Sixteenth to the Early Twentieth Century." Demography 58:111-135.

The British Library. 2021. Database of Italian Academies. https://www.bl.uk/catalogues/ ItalianAcademies/About.aspx. 